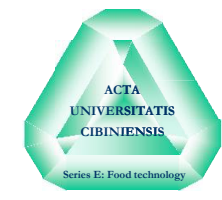

\title{
ANTIMICROBIAL EFFECT OF ESCHERICHIA COLI ON ESSENTIAL OILS DERIVED FROM ROMANIAN AROMATIC PLANTS
}

\author{
Daniela Maria ŞANDRU ${ }^{1}$
}
PhD Fellow, SOP HRD/159/1.5/S/133675 Project, Romanian Academy Iasi Branch or "Lucian Blaga" University from Sibiu, Partner

\begin{abstract}
This paper investigates the antimicrobial action of Escherichia coli $\mathrm{ATCC}^{\mathrm{R}}$ CRM-8739 $9^{\mathrm{TM}}$ on the following essential oils: Teucrium marum, Pinus sylwestris, Thymus vulgaris, Salviae aethedaroleum, Cinnamomum aromaticum, Hippophae rhamnoides, Lavandula angustifolia, Abies alba, Zingiber officinale, Anethum graveolens, Coriandrum sativum, Origanum vulgare, extracted industrialy from romanian plants, using the diffusion disc method. The most intense activity was observed at the essential oil of Cinnamomum aromaticum (cinnamon) and the mildest activity was observed at Zingiber officinale (ginger). Many of the essential oils tested exhibited moderate antimicrobial activity, as Teucrium marum, Thymus vulgaris, Hippophae rhamnoides, Lavandula angustifolia, Coriandrum sativum. The lowest antibacterial activity was exhibited on Pinus sylwestris, Salviae aethedaroleum, Zingiber officinale and Anethum graveolens.
\end{abstract}

Keywords: essential oils, Escherichia coli, fountain water, antimicrobial effects

\section{INTRODUCTION}

The beneficial effects of some plant extracts in healing or treating diseases were known from ancient times, and they can be found in popular medicine (Tabata et al., 1988). Later on, people attempted to understand these phenomena and to identify the compounds that confer these properties. Currently, there are over 30.000 plants with medicinal applications known

\footnotetext{
${ }^{1}$ Corresponding author. Mailing address: University "Lucian Blaga" of Sibiu, Faculty of Agricultural Sciences, Food Industry and Environmental Protection, Str. I. Raţiu 7-9, 550012 Sibiu, Romania. Phone: 0040/269/211338. Fax: 0040269212558. E-mail address: danielaraulea@yahoo.com
} 
worldwide (Koshy et al., 2009; Martinez-Valverde et al., 2002). The properties of these plants are based on their composition that is rich in bioactive compounds such as essential oils, tannins, flavonoids or polyphenols. The essential oils extracted from plants contain terpenes and its subclasses: monoterpenes, diterpenes, sesquiterpenes, which have antibacterial, anti-septic, anti-inflammatory or anti-viral properties (Wallace, 2004; Georgescu and Mironescu, 2011). The antimicrobial activity of the essential oils that can be found in the plants is due to compounds such as carvacrol, camphor, terpinen-4-olul or thymol, and their activity is beneficial for the human organism, with more and more applications in the pharmaceutical or food industry (Hadizadeh et al., 2009; Ali-Shtayeh et al., 2008; Bhaskara et al., 1998).

Most of the time, infections emerge in the organism due to external factors, like the consumption of contaminated food, infested water or other affected sources as buildings (Mironescu and Georgescu, 2010). In Romanian villages, the consumption of water from fountains is a problem, as these waters are frequently contaminated with coliform bacteria that can appear in groundwater from fecal sources. The coliform bacteria Escherichia coli dominates both surface water and groundwater, especially water originating from areas contaminated with animal sewage or where hygiene is deficient (Oprean et al., 2013; Iancu et al., 2013; Stegăruș et al., 2013).

Using the aromatic plants in the daily life under various forms, the organism acquires natural immunity to contaminating factors, such as bacteria Escherichia coli. This paper aims to analyse the antimicrobial effect on the following essential oils: Teucrium marum, Pinus sylwestris, Thymus vulgaris, Salviae aethedaroleum, Cinnamomum aromaticum, Hippophae rhamnoides, Lavandula angustifolia, Abies alba, Zingiber officinale, Anethum graveolens, Coriandrum sativum, Origanum vulgare, extracted from industrial plants, of the contamination microorganism Escherichia coli.

\section{MATERIALS AND METHODS}

Essential oils from Teucrium marum, Pinus sylwestris, Thymus vulgaris, Salviae aethedaroleum, Cinnamomum aromaticum, Hippophae rhamnoides, Lavandula angustifolia, Abies alba, Zingiber officinale, Anethum graveolens, Coriandrum sativum, Origanum vulgare were used.

The microorganism Escherichia coli $\mathrm{ATCC}^{\mathrm{R}}$ CRM-8739 ${ }^{\mathrm{TM}}$ (for research only) was used (concentration $10^{6}$ cells $/ \mathrm{mL}$ ).

Culture medium Eosin methylene blue agar (EMB) (Scharlau Chemie S.A., Barcelona, Spain) with the following composition: peptone $10 \mathrm{~g}$, lactose $10 \mathrm{~g}$, 
Dipotassium hydrogen phosphate $2 \mathrm{~g}$, Eosin Y $0.4 \mathrm{~g}$, Methylene blue $0.065 \mathrm{~g}$, Agar $15 \mathrm{~g}$ was used. The medium was prepared according to the producer's recipe, autoclaved and cooled.

Other materials were: $6 \mathrm{~mm}$ diameter sterile paper filter discs, $90 \mathrm{~mm}$ diameter Petri dishes.

The antibiogram method was used, consisting in the following steps:b1 ml droplets of bacterial culture (Escherichia coli EC 218, concentration $10^{6}$ cells $/ \mathrm{mL}$ ) were added in each of the 36 Petri dishes, over which the melted culture medium containing Eosin methylene blue agar was added and cooled at $40^{\circ} \mathrm{C}$. The culture was homogenized with the culture medium and then it was cooled at room temperature. After solidification, it was added the discs impregnated with essential oils in each dish $(100 \mu \mathrm{l} /$ disc $)$ as follows: 1 . Teucrium marum, 2. Pinus sylwestris, 3. Thymus vulgaris, 4. Salviae aethedaroleum, 5. Cinnamomum aromaticum, 6. Hippophae rhamnoides, 7. Lavandula angustifolia, 8. Abies alba, 9. Zingiber officinale, 10. Anethum graveolens, 11. Coriandrum sativum, 12. Origanum vulgare (4 discs/dish). The dishes were incubated at $37^{\circ} \mathrm{C}$ for $48 \mathrm{~h}$. The anti-microbial effect of the 12 essential oils was monitored by measuring the diameter of inhibition around the discs after $48 \mathrm{~h}$ of incubation at $37^{\circ} \mathrm{C}$, then after $72 \mathrm{~h}$ and after 90 h. Finally, the average was determined for the same lots of essential oils.

\section{RESULTS AND DISCUSSIONS}

The results obtained experimentally are presented in Table 1. The antimicrobial activity of the essential oils has been proven by the inhibition of bacteria growth in the impact zone of the discs with the culture of microorganisms. It can be seen that each oil has a different action, the inhibition zone ranging from $6.1 \mathrm{~mm}$ for Zingiber officinales and $20.2 \mathrm{~mm}$ for Cinnamomum aromaticum, after the first measurement at $48 \mathrm{~h}$. Similar values are exhibited by Thymus bulgaris and Hippophae rhamnoides, of 8.2 $\mathrm{mm}$, and Pinus sylwestris, Silviae aethedaroleum and Anethum graveolens of 7.1-7.2 mm. A 30\% higher percentage can be observed in the case of Coriandrum sativum, whereas Origanum vulgare and Abies alba produce an inhibition of the reference zone of $17.3 \mathrm{~mm}$. Teucrium marum has an average reference zone with a value of $9.2 \mathrm{~mm}$.

After $72 \mathrm{~h}$, the most powerful action is noticeable in Cinnamomum aromaticum where measured values reached $21.1 \mathrm{~mm}$, the difference between the first measurement and the second being 3.8\%. Zingiber officinale has the weakest antimicrobial activity, where measured values do not exceed $6,5 \mathrm{~mm}$. Modest values are exhibited also by Pinus sylwestris, with a value of $7.3 \mathrm{~mm}$, 
Salviae aethedaroleum with $7.4 \mathrm{~mm}$, Anethum graveolens, with $7.3 \mathrm{~mm}$. The power of Teucrium marum is 50\% lower than that of Abies alba or $51.2 \%$ lower than Origanum vulgare.

Table 1. Antimicrobial activity of essential oils on the growth of the Escherichia coli EC 218 measured in $\mathrm{mm}$ after $48 \mathrm{~h}, 72 \mathrm{~h}$, and $96 \mathrm{~h}$.

\begin{tabular}{|l|l|l|l|l|}
\hline \multirow{2}{*}{ No. } & \multirow{2}{*}{ Name of the essential oil } & \multicolumn{3}{|c|}{ Measured values of the inhibition diameter, } \\
\cline { 3 - 5 } & & after $48 \mathrm{~h}$ & after $72 \mathrm{~h}$ & after $96 \mathrm{~h}$ \\
\hline 1 & Teucrium marum & 9.2 & 9.7 & 9.8 \\
\hline 2 & Pinus sylwestris & 7.1 & 7.3 & 7.4 \\
\hline 3 & Thymus vulgaris & 8.2 & 8.4 & 8.4 \\
\hline 4 & Salviae aethedaroleum & 7.1 & 7.4 & 7.5 \\
\hline 5 & Cinnamomum aromaticum & 20.2 & 21.1 & 21.2 \\
\hline 6 & Hippophae rhamnoides & 8.2 & 8.5 & 8.7 \\
\hline 7 & Lavandula angustifolia & 12.5 & 13.2 & 13.5 \\
\hline 8 & Abies alba & 17.3 & 18.1 & 18.1 \\
\hline 9 & Zingiber officinale & 6.1 & 6.5 & 6.7 \\
\hline 10 & Anethum graveolens & 7.2 & 7.3 & 7.3 \\
\hline 11 & Coriandrum sativum & 10.7 & 11.1 & 11.3 \\
\hline 12 & Origanum vulgare & 17.3 & 19.1 & 19.3 \\
\hline It
\end{tabular}

It can be seen that the action of oils weakens, and it is slightly higher or even equal with the previous one. The same can be said of Thymus vulgaris with a value of $8.4 \mathrm{~mm}$ measured after $72 \mathrm{~h}$ and after $96 \mathrm{~h}$. Cinnamonum aromaticum maintains its powerful antimicrobial character managing to inhibit the growth of bacteria after $96 \mathrm{~h}$ up to $21.2 \mathrm{~mm}$. Teucrium marum has a moderate strength of inhibition, its values not surpassing $9.8 \mathrm{~mm}$. Salviae aethdaroleum has a modest evolution, considering that the antibacterial action is limited, and so do Zingiber officinale and Anethum graveolens. Abies alba and Origanum vulgare feature an intense activity of inhibition of the growth of the Escherichia coli, the final results ranging from $18.1 \mathrm{~mm}$ to $19.3 \mathrm{~mm}$.

These results are in accordance with other similar researches on volatile oils extracted from romanian plants (Mironescu et al., 2009).

\section{CONCLUSION}

From the obtained results it can be concluded that the selected essential oils feature antimicrobial activity. The essential oils of Cinnamomum aromaticum, Origanum vulgare and Abies alba exhibited superior antimicrobial effects. The following essential oils exhibited moderate 
antimicrobial activity: Teucrium marum, Thymus vulgaris, Hippophae rhamnoides, Lavandula angustifolia,Coriandrum sativum, and the lowest such activity was exhibited by Pinus sylwestris, Salviae aethedaroleum, Zingiber officinale and Anethum graveolens. The antimicrobial properties of these essential oils can lead to their utilization in the treatment of various disease caused by Escherichia coli.

\section{ACKNOWLEDGEMENTS}

This paper is supported by the Sectoral Operational Programme Human ResourcesDevelopment (SOP HRD), financed from the European Social Fund and by the Romanian Government under the contract number POSDRU/159/1.5/S/133675.

\section{REFERENCES}

1. Ali-Shtayeh M. S., Jamous R. M, Al-Shafie J. H., Elgharabah W. A. (2008) Traditional knowledge of wild edible plants used in Palestine (Northern West Bank): A comparative study, J. Ethnobio. Ethnomed.,doi: 10.1186/1746-4269-4-13

2. Bhaskara M. V., Angers P., Gosseline A., Arul J. (1998). Characterization and use of essential oil from Thymus vulgaris against Botrytis cinerea and Rhizopus stolonnifer in strawberry fruits, Phytochem., 47, 1515- 1520

3. Georgescu C., Mironescu M. (2011). Obtaining, characterisation and screening of the antifungal activity of the volatile oil extracted from Thymus serpyllum, J. Env. Prot. Ecol., 12, 4A, 2294-2302

4. Hadizadeh I., Peivastegan B., Hamzehzarghani H. (2009). Antifungal activity of essential oils from some medicinal plants of Iran against Alternaria alternate, Am. J. Appl. sci., 6, 857-861.

5. Iancu, R., Letiţia Oprean, Diana Stegăruş,Ovidiu Tiţa, Adrian Boicean, Ecaterina Lengyel,(2013),Environmental indicators of water quality in the Cibin River, Romania, Transylvanian Review of Systematical and Ecological Research - The Wetlands Diversity 2013 , 91-106

6. Koshy P., Nurestri A., Wirakaranain S., Sim K., Saravana K.(2009).Antimicrobial activity of some medicinal plants from Malaysia, Am. J. Appl. Sci., 6 (8), 1613-1617

7. Ljubuncic P., Dakwar S., Portnaya I., Cogan U., Azaizeh H., Bomazen A.(2006). Aqueous extract of Teucrium polium possess remarkable antioxidant activity in vetro, eCAM, 3(3), 329-338

8. Martinez-Valverde I., Periago M. J., Provan G., Chesson A. (2002).Phenolic compounds, lycopene and antioxidant activity in 
commercialvarieties of tomato (Lycopersicum esculentum), J. Sci. Food Agr., 82,323-330

9. Mironescu M., Georgescu C. (2010). Activity of some essential oils against common spoilage fungi of buildings, Acta Univ. Cib.. Series E: Food Tech, 14 (2), 41-46

10. Mironescu M., Georgescu C., Oprean L. (2009). Comparative sporicidal effects of volatile oils, Journal of agroalimentary processes and technologies, 15, 3, 361-365

11. Murray, P. R., Baron, E. J., Pfaller, M. A., Tenover, $F_{\text {th }}$ C. and Yolke, R. H. (1995). Manual of Clinical Microbiology, 6 edition. ASM, Washington, DC.

12. Oprean, L., Ecaterina Lengyel and Ramona Iancu, (2013), Monitoring and evaluation of Timiş River water quality based on physicochemical and microbiological analysis Transylvanian Review of Systematical and Ecological Research-Timiş River Basin 2013, 23-32

13. Stegarus, D.,Claudia Sandru, Ioan Stefanescu, Ovidiu Tita, Ramona Iancu, Mariana-Liliana Pacala, Ecaterina Lengyel, (2013), The monitoring of the physical-chemical and bacteriological indicators of Cibin river in view of quality classification, Conference proceeding, International Multidisciplinary Scientific Geoconference, SGEM 2013, Albena Bulgaria, Advances in Biotechnology, ISSN 1314-2704, 10451052

14. Tabata M., Honda G., Sezik E. (1988). A report on traditional medicine and medicinal plants in Turkey. Faculty of harmaceutical sciences, KyotoUniversity

15. Wallace, R. J., (2004), Antimicrobial properties of plant secondary metabolites, Proc. Nutr. Soc. 63, 621-629 